\title{
A Sand County Almanac at 70: the significance of Leopold's life-work for socio-ecological practice and research
}

\author{
Lin Qi Feng ${ }^{1}$
}

(c) Springer Nature Singapore Pte Ltd. 2020

American conservationist Aldo Leopold's A Sand County Almanac and Sketches Here and There (hereafter ASCA) was published in October 1949 and became a classic text in American conservation, environmentalism, and environmental (sub)disciplines. The continuing influence of ASCA after 70 years can be attributed to Leopold's extensive and deep experience in conservation, his affection for the land and ability to communicate it, and the title's rise to prominence during the environmental movement in the USA in the 1960s and 1970s. These reasons are necessary but insufficient.

To advance our understanding, we need to ask: Why do environmental practitioners and scholars continue to turn to ASCA 70 years later? The reasons above hint at the answer: we are still striving to realize Leopold's ideals of "land health" through the widespread embracing of an "ecological conscience" and a "land ethic" $(1949$, p. 221$)$ in societies around the world. Leopold completed his manuscript in the transformative and anxious years immediately following World War II, when bold international developments were in motion for better or worse. Leopold soberly noted some developments, e.g., the synecdoche (Tallmadge 1987, pp. 116-117) of "Mr. DuPont's nylon" and "Mr. Vannevar Bush's bomb" (Bush 1945; Leopold 1949, p. 110). Nevertheless, he ended the book by sharing his ecological conservation philosophy, distilling the essence of his ruminations from the prior 15 years or so. The environmental awakening of the 1960s and 1970s might have led to greater attention to environmental protection, but environmental insults have mounted up to the present-some, like our incessant emission of greenhouse gases, quite insidiously. Environmental practitioners and scholars have realized that resolving our environmental predicament depends as much, if not more,

Lin Qi Feng

qflin@ntu.edu.sg

1 School of Humanities, Nanyang Technological University, 48 Nanyang Avenue, SHHK-05-16, Singapore 639818, Singapore on social and political factors than on science and technology. Leopold realized this as well: while he discussed "the land" and conservation in his writings, he also commented on the social and cultural dimensions of conservation and the human-land or human-environment relationships. In the last part ("The Upshot") of ASCA, Leopold examined the significance of land and conservation to American society.

This is not to suggest that Leopold's thinking-that instilling in individuals and society an ecological conscience would lead to the development of individual and societal land ethics, which in turn would promote land health-constitutes the last word on human-environment relationships. However, that Leopold's (1949) book still speaks to our contemporary environmental predicament suggests that Leopold identified major foundational issues that remain unresolved: chiefly, our treatment of the natural world as merely a fund of resources, the relentless exploitation of which may threaten our very own existence. Nevertheless, Leopold was pragmatic enough to recognize that economic thinking will continue to drive decision making. He pleaded for tempering economic logic with the insights and principles of ecology, evolutionary science, ethics, and esthetics.

Socio-Ecological Practice Research (SEPR) was founded in 2019 to promote "transdisciplinary inquiry that strives to achieve the dual ambition of producing new knowledge and improving socio-ecological practice" (Xiang 2019, p. 1). Leopold's $A S C A$ was cited in some of the journal's first articles. In particular, Steiner (2019) discussed Leopold's "esthetic" of the land (Leopold 1949, pp. 165-177). The recent discussion by Assmuth et al. (2019) on "transdisciplinary health" echoes Leopold's land health concept (Leopold 1999). In retrospect, Leopold's life-work could be interpreted as a continuous exploration of socio-ecological practice and research, a life-long reiterative process of learning, practice, and reflection through which he sought to achieve conservation as "a state of harmony between men and land" (Leopold 1949, p. 207). He committed mistakes 
along the way, as he confessed in the essay "Thinking Like a Mountain" (pp. 129-133).

To commemorate the 70th anniversary of $A S C A^{1}$ and with the support of SEPR's editor-in-chief Wei-Ning Xiang, I am pleased to present this special section which contains three articles. Developing Leopold's thinking in different directions, the authors provide contemporary yet historically informed perspectives on Leopold. The first article is my review on Leopold's life-work and secondary scholarly literature, the latter including race and diversity, history, science, conservation philosophy, ecocriticism, land use policy, and conservation economics. In the second article, Paul Van Auken examines the bifurcation of the community concept in sociology and ecology in the twentieth century. Responding to Leopold's comment about the "inevitable fusion" of the "two lines of thought" of human ecology and plant and animal ecology ([1935] 2013, p. 375), Van Auken develops the landscape interactional field extension (LIFE) of community as a step toward reconciling ecological and sociological community concepts. In the third article, Curt Meine interprets Leopold's thinking about humans and land through socio-ecological systems and systems thinking, and reviews these ideas in their historical context. The special section ends with an annotated bibliography tailored to the socio-ecological practice and research community. It contains Leopold's published writings, historically oriented secondary literature that interpret Leopold, and illuminative readings that project to the present and future.

Leopold's experiences at the interface of socio-ecological practice and research in conservation gave him many an opportunity to reflect on the human-environment relationship. His oeuvre and the restored landscape of his farm near Baraboo, Wisconsin, in the USA record his intellectual journey and affection for the land. As we develop our own thinking on human-environment relationships, either explicitly or implicitly, theoretically or practically, I hope that practitioners and scholars who draw on Leopold would view SEPR as a suitable platform for publishing their writings. I hope too that practitioners and scholars in general continue to reconcile the social and the ecological dimensions of their work, and to address people's emotional responses toward the environment.
Acknowledgements For their help in reviewing abstracts, I thank our advisory committee which consists of J. Baird Callicott, Susan Flader, Richard Knight, Curt Meine, Bryan Norton, Stanley Temple, and Julianne Warren. I also thank the scholars who reviewed the manuscripts. Last but not least, I am especially grateful to Wei-Ning Xiang, the editor-in-chief of $S E P R$, for his guidance and support, and Curt Meine for his editorial advice.

\section{References}

Assmuth T et al (2019) Integrative concepts and practices of health in transdisciplinary social ecology. Soc Ecol Pract Res. https://doi. org/10.1007/s42532-019-00038-y

Bush V (1945) Science: the endless frontier; a report to the president on a program for postwar scientific research. United States Government Printing Office, Washington, DC

Leopold A (1949) A Sand County Almanac and sketches here and there. Oxford University Press, New York

Leopold A (1999) For the health of the land: previously unpublished essays and other writings. Island Press, Washington, DC

Leopold A ([1935] 2013) Wilderness ("The two great cultural advances..."). In: Meine C (ed) A Sand County Almanac \& other writings on ecology and conservation. The Library of America, New York, p 375

Steiner F (2019) Toward an ecological aesthetic. Soc Ecol Pract Res 1:33-37. https://doi.org/10.1007/s42532-018-00004-0

Tallmadge J (1987) Anatomy of a classic. In: Callicott JB (ed) Companion to A Sand County Almanac: interpretive and critical essays. University of Wisconsin Press, Madison, pp 110-127

Xiang W-N (2019) Socio-Ecological Practice Research (SEPR): What does the journal have to offer? Soc Ecol Pract Res 1:1-5. https:// doi.org/10.1007/s42532-018-0001-y

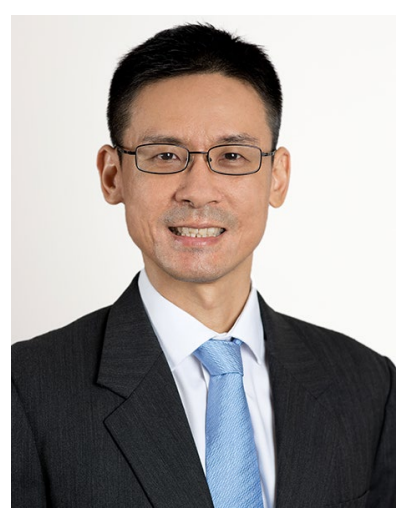

Lin Qi Feng received his Ph.D. from the Department of Natural Resources Sciences at McGill University and Master's degree from the Yale University School of Forestry \& Environmental Studies. He is currently researching on Aldo Leopold as a postdoctoral fellow at the History Programme at Nanyang Technological University, Singapore. His publications include articles on Aldo Leopold, climate change, and Singapore's environment.

$\overline{1}$ With some allowance for academic and publishing delays. 